\title{
Concerning Chapter 5 - Human Albumin; in Cross- Sectional Guidelines for Therapy with Blood Components and Plasma Derivatives, 4th ed. Transfus Med Hemother 2009;36(6):399-407
}

\author{
Albert Farrugia \\ Plasma Protein Therapeutics Association, Annapolis, MD, USA
}

The most recent edition of the Cross-Sectional Guidelines for Therapy with Blood Components and Plasma Derivatives are provided generously and freely in the December 2009 issue of Transfusion Medicine and Hemotherapy. As with previous editions, these guidelines are a reflection of the state of the art in transfusion medicine, and they will continue to be of great value to practicing clinicians. Their adherence to the principles of evidence based medicine (EBM) should provide the best foundation for the use of hemotherapies for manufactures and users alike. Some of the hierarchical principles of EBM have to be addressed differently for products such as plasma protein therapies when small patient numbers place limitations on the levels of statistical power achievable in clinical trials, compared to the pharmaceuticals used on large numbers of patients in highly prevalent disease states, such as the cardiovascular problems, addressed through the Guidelines' cited reference for assignment with the level of evidence.

The usage of albumin, while being embedded in medical practice for the past 70 years, is based more on historical precedent and clinical observation than on randomized clinical trials. Nevertheless, a growing body of evidence, using the conventional tenets of EBM, supports the use of albumin in various areas of clinical practice. The Guidelines state that "A meta-analysis of the "Cochrane Injuries Group Albumin Reviewers" published in 1998 has led to a negative assessment regarding the use of human albumin'. This analysis has been discredited through demonstration of errors [1], through the results of pharmacovigilance [2], and through the SAFE trial [3]. Allusion to this exercise is scarcely merited in a scholarly assessment as is found in the Guidelines. The Guidelines' constant allusion to the lack of a mortality endpoint advantage in trials comparing albumin to other modalities needs to recognize that such a comparison of one colloid over another colloid or a crystalloid would require over 6,500 patients to detect an excess mortality of $4 \%$ by one treatment over the other [4].So far, this has only been achieved with the SAFE trial, where the overall equivalence over a heterogeneous population of intensive care patients hides the benefits of albumin in e.g. sepsis as indicated by subgroup analysis. With small patient populations in resource challenged environments such patient numbers are unfeasible. While prospective subgroup analyses have not been performed in the majority of instances, scrutiny of individual trials within the meta-analyses, as is recommended by advocates of EBM [5], reveals findings of clinical relevance. For example, in the pediatric trials within the meta-analyses of Alderson et al. [6], Bland et al. [1] found a survival advantage with albumin compared to dextrose for low birth weight infants at risk of respiratory distress, while Kanarek et al. [7] found enhanced weight gain and relief in hypotension in a similar group. Brown et al. [8] found lower rates of septicemia and pneumonia in hypoalbuminemic infants on total parenteral nutrition given albumin, and pointed out that the numbers of patients required to detect other outcomes were not practically achievable in these trials.

The Guidelines appear to preclude the use of albumin in most instances, particularly in acute care, through the presumption that rapid infusion is impossible because of storage container issues. This is incorrect as albumin solutions are available in flexible plastic containers. Because of this underlying (incorrect) presumption that rapid infusion of albumin is not possible, the Guidelines advocate the use of alternative volume expanders which are claimed to be therapeutically equivalent to albumin in safety and efficacy. The alternative expanders specified in the Guidelines - the hydroxyethyl starches (HES) - have recently been the subject of two meta-

\section{KARGER}

Fax +497614520714

Information@Karger.de

www.karger.com (c) 2010 S. Karger GmbH, Freiburg

Accessible online at:

www.karger.com/tmh 
analyses concluding that intensive care patients, particularly those with sepsis or septic shock, had a higher risk of renal damage when treated with HES $[9,10]$. This was observed across the whole range of HES preparations, including the recent formulation of lower molecular weight and degree of substitution. Similarly, bleeding problems have been prevalent for the molecular weight $200 \mathrm{kDa}$, MS 0.5 formulation of these agents [11], despite the assertion made in the Guidelines $[12$, p. 402]. It is clear that problems associated with HES bleeding and renal dysfunction - are found in the whole range of HES preparations trialed up to now, including the most recent 'third generation' (130 kDa, MS 0.4) product [13-15].

The Guidelines acknowledge albumin's benefit in treating some of the complications of liver disease but dismiss albumin's role in transport and toxin removal and scavenging. In the treatment of spontaneous bacterial peritonitis, albumin's benefit is recognized in the Guidelines and is at least partly due to the removal of nitric oxide products, and tumor necrosis factor in both plasma and ascitic fluid [16]. Albumin's physiological role in binding toxins has been the basis of the concept of albumin-assisted hemodialysis in patients with liver dysfunction. The Molecular Adsorbent Recirculating System (MARS ${ }^{\oplus}$; Teraklin AG, Rostock Germany) [17] when used in acute liver failure leads to an improvement in clinical, hemodynamic and neurological conditions, while reducing blood levels of bilirubin and ammonia [18]. Comparison to a non-albumin detoxification device showed significantly superior outcomes with MARS, indicating that the binding of toxins with albumin is important [19].

In summary, the benefits of albumin, and the risks of alternative therapies, are understated in these Guidelines. It is to be hoped that future iterations will address some of these deficiencies.

\section{Conflict of interest}

The author provides contractual services to the Plasma Protein Therapeutics Association, which represents the manufacturers of albumin and other plasma products.

\section{References}

1 Bland RD, Clarke TL, Harden LB, et al: Early albumin infusion to infants at risk for respiratory distress. Arch Dis Child 1973;48:800-805.

2 Vincent JL, Wilkes MM, Navickis RJ: Safety of human albumin: serious adverse events reported worldwide in 1998-2000. Br J Anaesth 2003;91: 625-630.

3 Finfer S, Bellomo R, Boyce N, et al: A comparison of albumin and saline for fluid resuscitation in the intensive care unit. N Engl J Med 2004;350:22472256.

14 Webb AR: Crystalloid or colloid for resuscitation. Are we any the wiser? Crit Care 1999;3:R25-R28.

5 Horwitz RI: Complexity and contradiction in clinical trial research. Am J Med 1987;82:498-510.

6 The Albumin Reviewers (Alderson P, Bunn F, Li Wan Po A, Li L, Pearson M, Roberts I,Schierhout G): Human albumin solution for resuscitation and volume expansion in critically ill patients. Cochrane Database Syst Rev 2004; 4. Art:CD001208. DOI: 10.1002/14651858.CD001208.pub2.

$>7$ Kanarek KS, Williams PR, Blair C: Concurrent administration of albumin with total parenteral nutrition in sick newborn infants. J Parenter Enteral Nutr 1992;16:49-53.

$>8$ Brown RO, Bradley JE, Bekemeyer WB, Luther RW: Effect of albumin supplementation during parenteral nutrition on hospital morbidity. Crit Care Med 1988;16:1177-1182.
9 Zarychanski R, Turgeon AF, Fergusson DA, Cook DJ, Hébert P, Bagshaw SM, Monsour D, McIntyre L: Renal outcomes and mortality following hydroxyethyl starch resuscitation of critically ill patients: systematic review and meta-analysis of randomized trials. Open Med 2009;3:e196-209.

10 Dart AB, Mutter TC, Ruth CA, Taback SP: Hydroxyethyl starch (HES) versus other fluid therapies: effects on kidney function. Cochrane Database Syst Rev 2010; 1:CD007594. DOI: 10.1002/14651858.CD007594.pub2.

11 Keyser EJ, Latter DA, Morin JE, Murshid AA, Denis F, de Varennes B: Pentastarch versus albumin in cardiopulmonary bypass prime: impact on blood loss. J Card Surg 1999;14:279-286.

12 Chapter 5 - Human albumin; in Cross-Sectional Guidelines for Therapy with Blood Components and Plasma Derivatives Published by The Board of the German Medical Association on the Recommendation of the Scientific Advisory Board, 4th revised ed. Transfus Med Hemother 2009;36:399-407.

13 Kozek-Langenecker SA, Jungheinrich C, Sauermann W, Van der Linden P: The effects of hydroxyethyl starch 130/0.4 (6\%) on blood loss and use of blood products in major surgery: a pooled analysis of randomized clinical trials. Anesth Analg 2008; 107:382-390
4 Schortgen F, Girou E, Deye N, Brochard L; CRYCO Study Group: The risk associated with hyperoncotic colloids in patients with shock. Intensive Care Med 2008;34:2157-2168.

15 Schramko AA, Suojaranta-Ylinen RT, Kuitunen AH, Kukkonen SI, Niemi TT: Rapidly degradable hydroxyethyl starch solutions impair blood coagulation after cardiac surgery: a prospective randomized trial. Anesth Analg 2009;108:30-36.

16 Chen TA, Tsao YC, Chen A, et al: Effect of intravenous albumin on endotoxin removal, cytokines, and nitric oxide production in patients with cirrhosis and spontaneous bacterial peritonitis. Scand J Gastroenterol 2009;44:619-625.

17 Mitzner SR, Stange J, Klammt S, et al: Extracorporeal detoxification using the molecular adsorbent recirculating system for critically ill patients with liver failure. J Am Soc Nephrol 2001;12(suppl 17): S75-S82.

18 Stefoni S, Colì L, Bolondi L, et al: Molecular adsorbent recirculating system (MARS) application in liver failure: Clinical and hemodepurative results in 22 patients. Int J Artif Organs 2006;29:207-218.

19 Laleman W, Wilmer A, Evenepoel P, et al: Effect of the molecular adsorbent recirculating system and Prometheus devices on systemic haemodynamics and vasoactive agents in patients with acuteon-chronic alcoholic liver failure. Crit Care 2006;10: R108. 